\title{
Screening of Finger Millet (Eleusine coracana) Varieties for Resistant to Blast (Magnaporthe grisea) Disease in Bastar District, Chhattisgarh, India
}

\author{
Prahlad Singh Netam ${ }^{1 *}$, Ashwani Kumar Thakur ${ }^{2}$, Prafull Kumar ${ }^{3}$ and R. S. Netam ${ }^{1}$ \\ ${ }^{1}$ Department of Plant Pathology, SG College of Agriculture and Research Station, \\ Jagdalpur, 494001 India \\ ${ }^{2}$ Department of Agronomy, SG College of Agriculture and Research Station, \\ Jagdalpur, 494001 India \\ ${ }^{3}$ Department of Genetics and Plant Breeding, SG College of Agriculture and Research \\ Station, Jagdalpur, 494001 India
}

*Corresponding author

\section{A B S T R A C T}

Keywords

Finger millet, Screening, Blast disease, Resistant, Susceptible

Article Info

Accepted:

20 November 2019

Available Online:

10 December 2019
The field experiment was conducted during Kharif 2018 at Saheed Gundadhur College of Agriculture and Research Station, Jagdalpur, IGKV, Raipur (CG), to identify the resistant sources for blast disease (Magnaporthe grisea). Result revealed that none of the varieties was found resistant against leaf blast. However, variety GPU $99(0.0 \%)$ was found resistant against neck blast and variety GPU 98 (2.41) and GSMC-1 (1.13) was promising for finger blast resistant. The mean of all location revealed that none of the entries were show resistant for leaf last. The incidence ranged from 9.15 to 23.56 , and 7.74 to 18.30 in neck blast and finger blast respectively.

\section{Introduction}

Small millets are the traditional crops, agronomically more adapted to less fertile soils. The important small millets grown in India are finger millet, kodo millet, little millet, foxtail millet, barnyard millet and proso millets (Netam et al., 2014). Finger millet (Eleusine coracana) is one of the major staple foods in tribal region of the rural community of Bastar, Chhattisgarh. It is commonly known as bird foot, maida, ragi in different place of India. Finger millet contributes to about 10 percent of the total area $(34.6 \mathrm{~m} \mathrm{ha})$ planted to millets (Patro et al., 2018). In India, finger millet ranks next to pearl millet and is cultivated on $2.6 \mathrm{~m}$ ha area with a production of about $3.0 \mathrm{mt}$ and accounts for $81 \%$ of the minor millets produced (Shastri, 1989). A number of 
constraints limit finger millet production and productivity. In India, blast is one of the major diseases causing recurring yield losses in all the state (Seetharam, 1983). Blast is the most destructive disease of finger millet because of its aggressiveness. Finger millet blast is caused by the fungus Magnaporthe grisea (anamorph Pyricularia grisea). The pathogen attacks all stages of crop development (vegetative and productive stages) (Mgonja $e t$ al., 2013).

\section{Materials and Methods}

Twenty four entries with one local check (udru millage) and one resistant check (GE 4449) under an initial varietal trail were conducted at New Upland Research Station cum Instructional Farm, Lamker under SG College of Agriculture and Research Station, Jagdalpur, Bastar (CG) during Kharif season 2018.

These entries were sown in two rows of 3 meter length and $22.5 \mathrm{~cm} \times 10 \mathrm{~cm}$ spacing with to find out resistant sources against blast disease of finger millet. The recommended agronomic practices were adopted at the time of crop growth. Infected plants were examined for lesion development and disease severity was assessed on the basis of lesion length by using 0 to 5 scale (Anonymous, 1995) (Table 1) Neck blast (\%) and finger blast (\%) was calculated by using the following formula:

Neck blast $(\%)=\frac{\text { No. of infected panicles }}{\text { Total number of panicle }} \times 100$

Finger blast $(\%)=$

No. of infected finger

Average no of finger Xtotal number of panicle

100

\section{Results and Discussion}

Twenty four entries were tested during Kharif 2018-19 with one local check (Udru mallige) and one resistant check (GE 4449) under Initial Varietal Trial. Disease incidence was recorded in 1 to 4 Grade $(\mathrm{G})$ for leaf blast, Neck blast 0.0 to $45.83 \%$ and Finger blast 1.13 to $25.17 \%$. Entry GPU $99(0.0 \%)$ shows tolerant against neck blast and entry, GPU 98 (2.41\%) and GSMC-1 (1.13\%) was found promising for finger blast resistant in Chhattisgarh state (Table 2).

Table.1 Standard Evaluation System (SES) scale for leaf blast disease

\begin{tabular}{|l|l|l|}
\hline Score & Description & Reaction \\
\hline $\mathbf{0}$ & No lesion/ symptoms on leaves & No disease/HR \\
\hline $\mathbf{1}$ & $\begin{array}{l}\text { Small brown specks of pinhead to slightly elongate, necrotic grey spots with a } \\
\text { brown margin, less than 1\% area affected }\end{array}$ & $\mathrm{R}$ \\
\hline $\mathbf{2}$ & A typical blast lesion elliptical, 5-10 mm long, 1-5\% of leaf area affected & MR \\
\hline $\mathbf{3}$ & A typical blast lesion elliptical, 1-2 cm long, 6-25\% of leaf area affected & MS \\
\hline $\mathbf{4}$ & 26-50\% leaf area affected & $\mathrm{S}$ \\
\hline $\mathbf{5}$ & More than 50\% of leaf area affected with coalescing lesions & HS \\
\hline
\end{tabular}


Table.2 Disease reaction of finger millet entries in Initial varietal trial against blast

\begin{tabular}{|c|c|c|c|c|c|c|c|}
\hline \multirow[t]{2}{*}{ S.N0 } & \multirow[t]{2}{*}{ Entry } & \multicolumn{3}{|c|}{ Bastar } & \multicolumn{3}{|c|}{ Mean of Eight centers } \\
\hline & & $\mathbf{L B}(\mathbf{G})$ & FB $(\%)$ & NB (\%) & $\mathbf{L B}(\mathbf{G})$ & FB $(\%)$ & NB (\%) \\
\hline 1 & WN 562 & 2.00 & 7.89 & 15.87 & 3.38 & 12.09 & 12.20 \\
\hline 2 & GPU 99 & 2.33 & 7.00 & 0.00 & 3.20 & 14.51 & 14.19 \\
\hline 3 & GPU 67 & 2.67 & 20.68 & 45.83 & 3.58 & 15.12 & 18.36 \\
\hline 4 & KMR 652 & 3.67 & 8.52 & 19.20 & 4.13 & 14.84 & 19.75 \\
\hline 5 & VR1117 & 2.00 & 8.16 & 13.70 & 3.33 & 11.86 & 12.85 \\
\hline 6 & VL 394 & 2.00 & 11.88 & 13.43 & 3.42 & 14.04 & 16.60 \\
\hline 7 & GPU 45 & 1.67 & 11.38 & 12.02 & 3.00 & 13.44 & 14.25 \\
\hline 8 & HR-13 & 1.67 & 25.17 & 12.75 & 3.13 & 16.20 & 14.20 \\
\hline 9 & KMR 650 & 1.33 & 17.40 & 23.33 & 2.62 & 7.74 & 9.15 \\
\hline 10 & RAUF 17 & 2.00 & 8.25 & 35.26 & 2.91 & 8.02 & 15.20 \\
\hline 11 & TNEc 1299 & 3.33 & 17.25 & 24.22 & 4.21 & 16.73 & 21.87 \\
\hline 12 & WN 591 & 2.33 & 11.29 & 8.37 & 3.17 & 14.44 & 14.86 \\
\hline 13 & VL 376 & 1.67 & 10.59 & 16.56 & 2.79 & 12.30 & 11.48 \\
\hline 14 & VR 1110 & 3.00 & 11.39 & 28.59 & 3.67 & 11.92 & 17.69 \\
\hline 15 & VL 382 & 2.00 & 6.39 & 31.31 & 3.63 & 13.22 & 19.06 \\
\hline 16 & BR-14-27 & 3.00 & 6.43 & 24.19 & 4.00 & 15.74 & 18.34 \\
\hline 17 & PR 202 & 3.33 & 14.06 & 38.73 & 3.63 & 18.30 & 19.82 \\
\hline 18 & TNEc 1297 & 3.67 & 12.65 & 34.60 & 3.46 & 17.65 & 23.48 \\
\hline 19 & GPU 98 & 2.00 & 2.41 & 13.75 & 3.21 & 11.70 & 13.75 \\
\hline 20 & OEB 604 & 2.33 & 11.83 & 14.29 & 3.54 & 9.83 & 11.13 \\
\hline 21 & PR 1639 & 3.33 & 16.24 & 9.03 & 3.67 & 15.59 & 14.86 \\
\hline 22 & IIMRFM-8023-17 & 3.33 & 9.56 & 27.21 & 4.50 & 16.85 & 23.56 \\
\hline 23 & IIMRFM-8011-17 & 1.33 & 3.92 & 24.38 & 3.08 & 11.21 & 13.21 \\
\hline 24 & GSMC-1 & 1.67 & 1.13 & 5.66 & 3.21 & 10.89 & 10.80 \\
\hline 25 & Resistant (GE 4449) & 2.33 & 6.58 & 13.10 & 2.02 & 5.27 & 4.92 \\
\hline 26 & $\begin{array}{l}\text { Local } \\
\text { (Udru mallige) }\end{array}$ & 3.33 & 15.96 & 35.73 & 5.67 & 31.48 & 34.86 \\
\hline & SEm \pm & 2.44 & 11.07 & 21.94 & 3.49 & 14.66 & 17.55 \\
\hline & C.D. $(5 \%)$ & 0.81 & 2.57 & 6.13 & 1.11 & 7.66 & 11.91 \\
\hline & C.V. $(\%)$ & 20.15 & 14.06 & 16.58 & 32.02 & 44.81 & 51.04 \\
\hline
\end{tabular}

LB-Leaf blast, NB-Neck blast, FB- Finger blast

The mean of eight locations over all India revealed that no entries were found resistant against leaf blast. The minimum severity percentage of neck blast $(9.15 \%)$ and in finger blast $(7.74 \%)$ was recorded in entry KMR 650 and maximum percentage of disease severity of neck blast was recorded in IIMRFM-802317(23.56\%),TNEc1297 (23.48\%) and TNEc $1299(21.87 \%)$ respectively and in finger blast entry PR 202 (18.30\%) show maximum percentage of disease severity. Patro et al., (2016) and Nagaraja et al., (2016) Screened 
12 elite finger millet cultivars among them, GE 4449 and GPU 28 were reported to be resistance to leaf blast and GE 4440, E 4449 and GPU 28 were moderate resistance/ susceptible to neck blast and finger blast.

Divya et al., (2017) screened 10 genotype were evaluated for resistance to blast none genotype were found free from disease incidence.

Minimum percentages of neck blast severity was recorded in VL 379 (14.82), while the minimum finger blast severity $(13.70 \%)$, was recorded in GPU-45.

Screening the twenty four varieties of initial varietal trial of finger millets with one resistant and one susceptible check. Variety GPU $99(0.0 \%)$ was found resistant against neck blast and, entry GPU $98(2.41 \%)$ and GSMC-1 (1.13\%) was promising for finger blast resistant during one year experimentation.

\section{Acknowledgement}

Authors acknowledge to All India Coordinated Research Project on Small Millets, ICAR. GKVK, campus, Bengaluru to provide the grant for experiment. The work was carried out at Saheed Gundadhur College of Agriculture and Research Station, Jagdalpur centre of IGKV, Raipur, and Chhattisgarh to provide all necessary facilities.

\section{References}

Anonymous (1995), Package of practices for high yielding verities, USA, Banglore, India.

Divya, M., Patro, T.S.S.K., Sandhya Rani, Y., Triveni, U. and Anuraha, N. 2017. Reaction of Eleusine coracana (L) Gaertn early and medium duration varieties against major maladies. Progressive Research - An international Journal, 12(1): 30-32.

Mgonja, M., Audi, P., Mgonja, A.P., Manyasa, E. and Ojulong, H. 2013. Integrated Blast and Weed Management and Microdosing in Finger Millet. A HOPE Project Manual for Increasing Finger Millet Productivity. Patancheru, Andhra Pradesh, India: International Crops Research Institute for the Semi-Arid Tropics.

Nagaraja, A., Bijendra Kumar, Jain, A,K., Patro, T.S.S.K., Nageswar Rao, T.G. 2016. Disease of Small millets. Diseases of field crop and their management. Indian Phytopahtological Society. New Delhi, 295-371.

Netam, R.S., Tiwari, R.K.S., Bahadur A. N., Singh, D. P. and Patel, D.P. 2014. Effect of sowing dates and meteorological factors on the development of blast disease in finger millet crop. American International Journal of Research in Formal, Applied \& Natural Sciences. IASIR, USA 2014, 01-05.

Patro, T.S.S.K., Neeraja, B., Sandhya Rani, Y., Jyothsna, S., Keerthi, S. and Bansal, A. 2016. Reaction of elite finger millet varieties against blast disease inciated by Magnapothe grisea in vivo. 11(2):209212.

Patro, T.S.S.K., Meena, A., Divya, M. and Anuradha, N. 2018. Screening of finger millet for major diseases and identification of resistant varieties. Journal of Pharmacognosy and Phytochemistry,7(3): 2681-2683.

Shastri, B.N. 1989. The wealth of India: A dictionary of Indian raw materials and industrial products. Publication and Information Directorate, CSIR, New Delhi. 160:6.

Seetharam, A. 1983. Identification of source of resistance to ragi blast and its utilization in breeding. In: National seminar $\mathrm{Br}$. Cr. Plant for Resistance to pest and diseases 25-27 May.TNAU, Coimbatore. 


\section{How to cite this article:}

Prahlad Singh Netam, Ashwani Kumar Thakur, Prafull Kumar and Netam, R. S. 2019. Screening of Finger Millet (Eleusine coracana) Varieties for Resistant to Blast (Magnaporthe grisea) Disease in Bastar District, Chhattisgarh, India. Int.J.Curr.Microbiol.App.Sci. 8(12): 2664-2668. doi: https://doi.org/10.20546/ijcmas.2019.812.311 